\title{
Bacterial Biofilm Degradation Using Extracellular Enzymes Produced by Penicillium janthinellum EU2D-21 under Submerged Fermentation
}

\author{
Anil Kumar Nagraj, Digambar Gokhale* \\ NCIM Resource Center, CSIR-National Chemical Laboratory, Pune, Maharashtra, India \\ Email: dv.gokhale@ncl.res.in
}

How to cite this paper: Nagraj, A.K. and Gokhale, D. (2018) Bacterial Biofilm Degradation Using Extracellular Enzymes Produced by Penicillium janthinellum EU2D-21 under Submerged Fermentation. Advances in Microbiology, 8, 687-698.

https://doi.org/10.4236/aim.2018.89046

Received: August 13, 2018

Accepted: September 14, 2018

Published: September 17, 2018

Copyright ( 92018 by authors and Scientific Research Publishing Inc. This work is licensed under the Creative Commons Attribution International License (CC BY 4.0).

http://creativecommons.org/licenses/by/4.0/

(c) (i) Open Access

\begin{abstract}
Bacterial biofilms are the bacterial aggregates that are embedded in the self-produced matrix of extracellular polymeric substances (EPS) that cause persistent bacterial infections posing significant medical challenges. They are recalcitrant to antibiotics and host defenses which make the treatments difficult and costly. Penicillium janthinellum mutant EU2D-21 was found to produce extracellular enzyme complex (amylase, cellulase, protease) under submerged fermentation. Maximum specific enzyme activities were found to be $3.04 \mathrm{IU} / \mathrm{mg}, 2.61 \mathrm{IU} / \mathrm{mg}$ and $3.39 \mathrm{IU} / \mathrm{mg}$ for alpha-amylase, cellulase and protease respectively, after 8 days of incubation at $30^{\circ} \mathrm{C}$. We evaluated the enzyme complex for its ability to target and degrade the biofilms of different bacteria. We found that it degraded biofilms of Escherichia coli (85.5\%), Salmonella enterica (79.72\%), Pseudomonas aeruginosa (88.76\%) and Staphyloccus aureus $(87.42 \%)$ within $1 \mathrm{~h}$ of incubation at $50^{\circ} \mathrm{C}$. The scanning electron microscopy (SEM), quantitation of biofilm removal assay and Crystal violet assay demonstrated that the enzyme complex detached the biofilm exo-polysaccharide matrix and bacteria from the cell surface. These results illustrate the feasibility and benefits of using this enzyme complex as anti-biofilm therapeutics to eradicate biofilms. This can also be used as a promising strategy to improve treatment of multidrug resistant bacterial infections.
\end{abstract}

\section{Keywords}

Penicillium janthinellum, Cellulase, Biofilm Degradation, Bacterial Biofilms

\section{Introduction}

Biofilms are complex structures associated with aggregates of microbes em- 
bedded in self-produced extracellular polymeric substances (EPS). EPS is composed of exo-polysaccharides, proteins and extracellular DNA (eDNA). Formation of biofilms provides significant advantage to microbial cells because it mediates adherence to host cells [1] [2] and assists in the resistance to antimicrobial agents [3]. The exopolysaccharide component of the biofilm acts as a barrier against phagocytosis by host immune cells [4]. It is estimated that most of the human bacterial infections $(60 \%-80 \%)$ are due to biofilms [5] and hence there is an urgent need to develop novel and effective treatments that target and disrupt biofilms. Biofilms are resistant to antimicrobial agents due to the impaired penetration and hence it is necessary to develop prophylactic treatments that either inhibit biofilm formation [6] [7] or disrupt the biofilms [8]. Pseudomonas aeruginosa is ubiquitous opportunistic pathogen causing pulmonary infections in immune-compromised patients who suffer from chronic lung diseases. Mortality is associated with $P$. aeruginosa is high [9] and it is increasing with the emergence of multidrug resistance strains. Recent studies have shown great interest in the use of enzymes in targeting and disrupting the bacterial biofilms proving their potential in treatment and eradication of chronic bacterial diseases. Staphylococcus aureus is a leading cause of infections in human population. It is very difficult to treat the wounds infected with $S$. aureus due to its multidrug resistance and natural tendency of biofilm formation. Watters et al. [10] tested the efficacy of the enzymes like $\alpha$-amylase, bromelain, lysostaphin against methicillin resistant strains of $S$. aureus biofilms and found that all of them decreased the biomass significantly within $24 \mathrm{~h}$. The fungal strain, Aspergillus clavatus MTCC 1323 was found to produce enzyme complex (protease, amylase, pectinase) which degrades the biofilms of $P$. aeruginosa, $B$. subtilis and $S$. aureus [11]. It is reported that glycoside hydrolases proved to be potential therapeutic agents exhibiting activity against diverse microorganisms by degrading biofilms [12]. Blanchette and Wenke [13] have very nicely highlighted the current and upcoming therapies for prevention and disruption of bacterial biofilms in their review article.

We therefore sought to look for the enzyme complexes capable of targeting and disrupting the biofilms of pathogenic bacteria. Penicillium janthinellum mutant EU2D-21, was known to produce cellulase enzyme complex [14]. We wanted to evaluate this enzyme complex for bacterial biofilm degradation and see whether it can be potential therapeutic agent for degrading bacterial biofilms. We demonstrate that the addition of low concentrations of the enzyme complex can disrupt bacterial biofilms in the laboratory strains of Pseudomonas aeruginosa, Escherichia coli, Salmonella enterica and Staphylococcus aureus in vitro at very low concentrations. Our results suggest that the enzyme complex produced by $P$. janthinellum have the potential to effectively degrade bacterial biofilm and can act as an anti-biofilm therapeutics which can be used for treatment and eradication of chronic bacterial infections. 


\section{Materials and Methods}

\subsection{Fungal Microbial Strain and Enzymes Production}

P. janthinellum mutant EU2D-21 was isolated in our laboratory [14] and was deposited in NCIM Resource Center, CSIR-National Chemical Laboratory, Pune, India with the accession no NCIM 1368. The strain was grown on Potato Dextrose Agar (PDA) slopes incubated at $30^{\circ} \mathrm{C}$ for 7 days and sub-cultured once in every 3 months. Bacterial strains Escherichia coli NCIM 2674, Salmonella enterica NCIM 2257, Pseudomonas aerogenosa NCIM 2200 and Staphylococcus aureus NCIM 5021 were obtained from NCIM Resource Center, CSIR-National Chemical Laboratory, Pune, India. Basal fermentation medium consisted of $0.2 \%$ $\mathrm{KH}_{2} \mathrm{PO}_{4}, 0.03 \% \mathrm{CaCl}_{2}, 0.03 \%$ urea, $0.14 \%\left(\mathrm{NH}_{4}\right)_{2} \mathrm{SO}_{4}, 0.01 \%$ yeast extract, $0.025 \%$ bacto-peptone, $0.03 \% \mathrm{MgSO}_{4} .7 \mathrm{H}_{2} \mathrm{O}, 0.0005 \% \mathrm{FeSO}_{4} .7 \mathrm{H}_{2} \mathrm{O}, 0.00016 \%$ $\mathrm{MnSO}_{4} \cdot 7 \mathrm{H}_{2} \mathrm{O}, 0.00014 \% \mathrm{ZnSO}_{4} \cdot 7 \mathrm{H}_{2} \mathrm{O}, 0.0002 \% \mathrm{CoCl}_{2}$ and $0.1 \%$ Tween 80 . The $\mathrm{pH}$ of the fermentation medium was adjusted to 5.2 prior to sterilization. Submerged fermentation $(\mathrm{SmF})$ was carried out in $250 \mathrm{ml}$ Erlenmeyer flask with 70 $\mathrm{ml}$ of fermentation medium containing cellulose powder (1\%) and wheat bran (2.5\%). The flasks were inoculated with spores (approximately $10^{7}$ ) from 15 -days old culture grown on PDA slant and incubated at $30^{\circ} \mathrm{C}$ with shaking at $180 \mathrm{rpm}$. The samples were removed after 8 days of incubation and centrifuged at 7500 $\mathrm{rpm}$ for $10 \mathrm{~min}$ at $10^{\circ} \mathrm{C}$. The supernatant was analyzed for cellulase, amylase, and protease enzymes. Protein was estimated according to Lowry method with bovine serum albumin as standard [15].

\subsection{Enzyme Assays}

Cellulase (FPase) was determined by DNS method as reported earlier [14]. The assay mixture of $2 \mathrm{ml}$ contained $1.9 \mathrm{ml}$ citrate buffer $(50 \mathrm{mM}, \mathrm{pH} 4.5)$ and Whatman filter paper no. $1(50 \mathrm{mg}, 2-6 \mathrm{~cm})$ and $0.1 \mathrm{ml}$ of suitably diluted supernatant. The reaction was initiated by the addition of enzyme and the assay mixture was incubated at $50^{\circ} \mathrm{C}$ for $60 \mathrm{~min}$. One unit (IU) of enzyme activity was defined as the amount of enzyme required to liberate $1 \mu \mathrm{mol}$ of glucose produced per min under the assay conditions. The $\alpha$-amylase activity was determined by the method of Bernfield [16]. The reaction mixture of $1 \mathrm{ml}$ consisting of $0.5 \mathrm{ml}$ of suitable diluted supernatant and $0.5 \mathrm{ml}$ of $1 \%$ soluble starch in 50 $\mathrm{mM}$ citrate buffer, $\mathrm{pH} 4.5$ was incubated at $50^{\circ} \mathrm{C}$ for $10 \mathrm{~min}$. The reducing sugars released were estimated as glucose equivalents by DNS method. One unit of enzyme activity was defined as 1 umole of sugar released per min per $\mathrm{ml}$ of culture filtrate. Protease activity was determined as reported earlier using Bovine Serum Albumin (BSA) as substrate [17]. The reaction mixture of $2 \mathrm{ml}$ contained $10 \mathrm{mg}$ of BSA in $50 \mathrm{mM}$ sodium citrate buffer, $\mathrm{pH} 4.5$ and suitably diluted culture filtrate containing the enzyme. The reaction was incubated for $60 \mathrm{~min}$ at $50^{\circ} \mathrm{C}$ and the reaction was terminated by adding $3 \mathrm{ml}$ of $5 \%$ tri-chloroacetic acid. The acid soluble material was estimated at $280 \mathrm{~nm}$ after removing the precipitate by filtration through Whatman No. 1 filter paper. One unit of activity was de- 
fined as the amount of enzyme which catalyzed the release of $1 \mu \mathrm{mol}$ of tyrosine per min per ml of the culture filtrate.

\subsection{Biofilm Treatment with Enzyme, Crystal Violet (CV) Assay and Scanning Electron Microscopy}

To test the efficacy of enzyme preparation, $1.5 \mathrm{ml}$ (Total protein $10 \mathrm{mg}, 5 \mathrm{mg}$, $2.5 \mathrm{mg}$ ) of filter sterilized crude enzyme in $50 \mathrm{mM}$ sodium citrate buffer, $\mathrm{pH} 4.5$ was added to each well and kept at $50^{\circ} \mathrm{C}$ for $1 \mathrm{hr}$ in Heidolph Titramax-1000 incubator with shaking $450 \mathrm{rpm}$. Wells containing citrate buffer without enzyme were used as control. After incubation for $1 \mathrm{~h}$, the degradation was visualized by $\mathrm{CV}$ assay. Crystal violet (CV) assay was performed as described by Trivedi et al. [18]. The washed biofilms were stained with $0.1 \%$ CV for $10 \mathrm{~min}$ and washed again with saline. The CV dye was eluted with $95 \%$ of ethanol and quantified by measuring $\mathrm{OD}_{600}$ with a microplate reader (Spectramaxplus 384 plate reader, Molecular Devices Inc.). Blank samples with LB in absence bacteria were included in all $\mathrm{CV}$ assays. The $\mathrm{OD}_{600}$ readings of the blanks were subtracted from the $\mathrm{OD}_{600}$ readings of the test samples to account for any non-specific binding of $\mathrm{CV}$ in the wells. A modified SEM method was used for analysis of biofilms of all four organisms [19]. All test samples were fixed in $2 \%$ glutaraldehyde at $4^{\circ} \mathrm{C}$ for $2 \mathrm{~h}$, washed with $100 \mathrm{mM}$ PBS two times and then dehydrated in a gradient alcohol concentration $(30 \%, 50 \%, 80 \%$, and $90 \%)$ in water for $10 \mathrm{~min}$ at $4^{\circ} \mathrm{C}$. The samples were further dehydrated with $100 \%$ ethanol at $4^{\circ} \mathrm{C}$ for $10 \mathrm{~min}$. The specimen was left in absolute alcohol and mounted onto an aluminum stub with carbon tape, sputter-coated with gold before examination.

\subsection{Effect of $\mathrm{pH}$ and Temperature on Biofilm Removal}

The optimum temperature of biofilm removal was determined by treating the biofilms with enzyme mixture containing $5 \mathrm{mg}$ of total protein in $50 \mathrm{mM}$ citrate buffer, $\mathrm{pH}$ 4.5. The biofilms along with the enzymes were incubated at different temperatures ranging from $40^{\circ} \mathrm{C}$ to $50^{\circ} \mathrm{C}$ for $1 \mathrm{~h}$ in shaking plate incubator (450 $\mathrm{rpm})$. The biofilms incubated in citrate buffer with no enzyme were considered as control. The effect of different $\mathrm{pH}$ on biofilm removal was determined by treating the biofilms in buffers at various $\mathrm{pH}(3.0-6.0)$ containing enzyme and incubating them at $50^{\circ} \mathrm{C}$ in shaking plate incubator $(450 \mathrm{rpm})$ with taking appropriate control. The removal of the biofilms was determined using CV assay as described earlier.

\subsection{Estimation of Carbohydrate and Protein Content of Biofilm}

For comparison between control vs enzyme treated biofilms, the EPS was extracted by modified formaldehyde- $\mathrm{NaOH}$ method [20]. Briefly, each well was added $1 \mathrm{ml}$ of $10 \%$ formaldehyde solution and kept at $4^{\circ} \mathrm{C}$ for $1 \mathrm{~h}$. The formaldehyde solution was removed gently and added $1 \mathrm{ml}$ of $1 \mathrm{M} \mathrm{NaOH}$ solution prepared in distilled water and kept at $4^{\circ} \mathrm{C}$ for $2 \mathrm{~h}$ under shaking. The suspension of 
each well was collected and filtered by 0.22 micron filter. The filtrate was dialyzed ( $3 \mathrm{kDa}$ membrane) against double distilled water. Total carbohydrate content of biofilms were determined by phenol-sulfuric method using glucose as standard [21] and the protein content was determined by Lowry Method using BSA as standard.

\section{Results}

\subsection{Determination of Enzyme Activity}

P. janthinellum EU2D-21 produced high amounts of extracellular cellulase (FPase), CMCase and $\beta$-glucosidase under submerged fermentation conditions. In addition to the cellulase, $P$. janthinellum EU2D-21 was found to produce amylase and protease enzymes under submerged fermentation. The specific activities of 2.8, 3.0 and $3.4 \mathrm{IU} / \mathrm{mg}$ were for cellulase, amylase and protease respectively (Table 1). This enzyme preparation was further evaluated for degradation of biofilms produced by Escherichia coli NCIM 2674, Salmonella enterica NCIM 2257, Pseudomonas aerogenosa NCIM 2200 and Staphylococcus aureus NCIM 5021.

\subsection{Evaluation of Enzyme Efficacy for Biofilm Degradation}

The crude extracellular enzyme preparation produced by fungal strain $P$. janthinellum EU2D-21 was used for the bacterial biofilm degradation. The CV assay was used to determine the activity of enzymes on biofilms. Crude extracellular enzyme (containing total $10 \mathrm{mg}$ of protein) showed the highest percentage removal of biofilms produced by Escherichia coli (85.5\%), Salmonella enterica (79.72\%), Pseudomonas aeruginosa (88.76\%) and Staphyloccus aureus (87.42\%) in 1 hour at $50^{\circ} \mathrm{C}$ (Figure $1(\mathrm{a})$ ). The removal of the biofilms by the enzyme was also analyzed visibly using CV assay (Figure $1(\mathrm{~b})$ ). SEM analysis confirmed that crude extract of $P$. janthinellum could effectively degrade the biofilms formed by all tested bacterial strains. The SEM observations of the biofilms revealed that the untreated biofilms were dense and looked like organized structure with clear marked microcolonies. However, the enzyme treated biofilms were lacking such structures (Figure 2) showing the consistency with the CV assay observations.

\subsection{Effect of $\mathrm{pH}$ and Temperature on Biofilm Reduction}

Maximum biofilms reduction was observed maximum at $\mathrm{pH} 4.5$ at $50^{\circ} \mathrm{C}$ with a significant loss $(>30 \%)$ of biofilm degradation ability at $\mathrm{pH} 3.0$ for each tested

Table 1. Enzyme activities of crude broth from $P$. janthinellum EU2D-21.

\begin{tabular}{cc}
\hline Enzyme & Specific Activity $(\mathrm{IU} / \mathrm{mg})$ \\
\hline Celllulase & 2.85 \\
Alpha-amylase & 3.08 \\
Protease & 3.46 \\
\hline
\end{tabular}




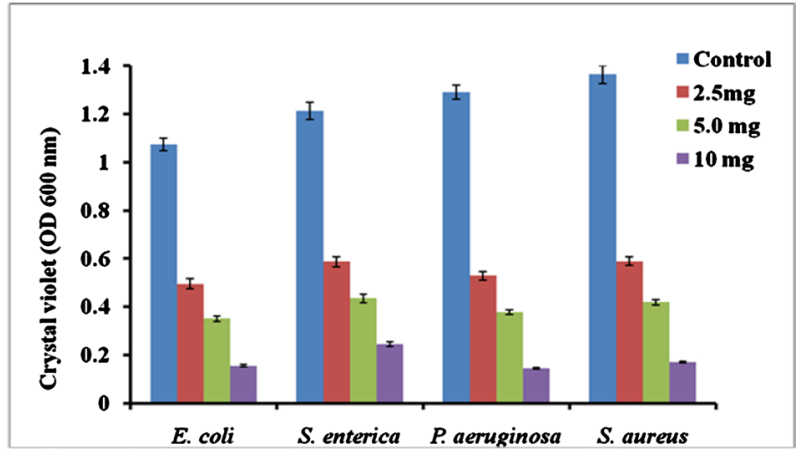

(a)

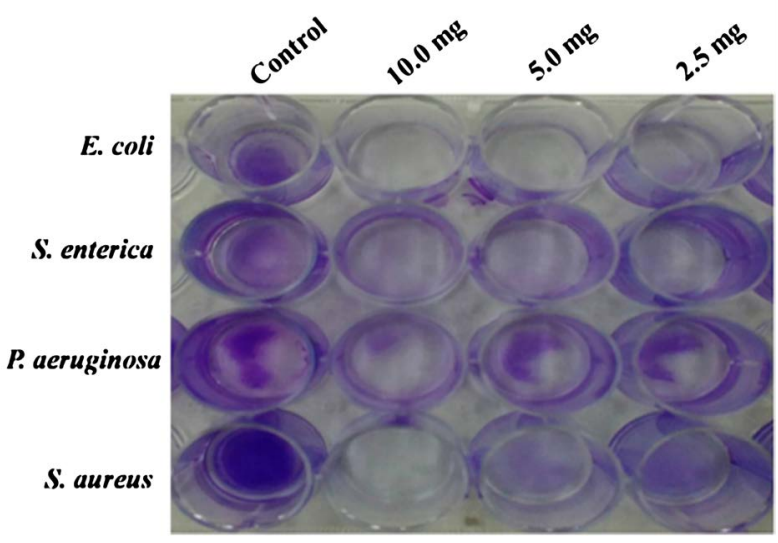

(b)

Figure 1. (a) Quantitative biofilm reduction using different concentration of enzyme range from 2.5 - $10 \mathrm{mg}$ produced by Penicillium janthinellum EU2D-21; (b) Wells of crystal violet staining with control biofims of each bacterial strain followed by enzyme treated at differnet total enzyme (total potein ranging from $2.5-10 \mathrm{mg}$ ).

\section{Control}

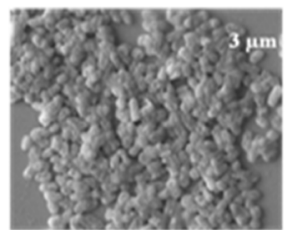

(a)

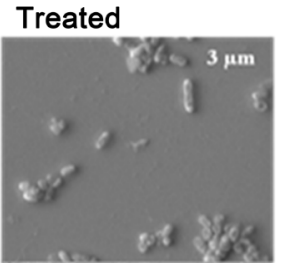

(e)

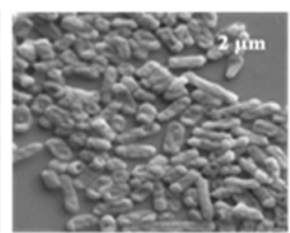

(b)

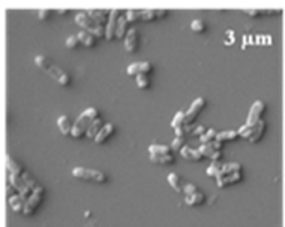

(f)

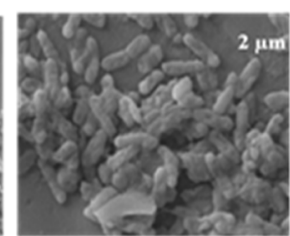

(c)

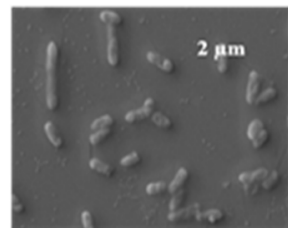

(g)

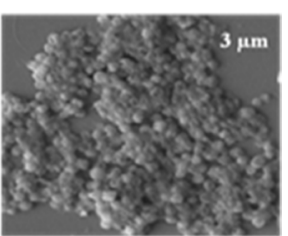

(d)

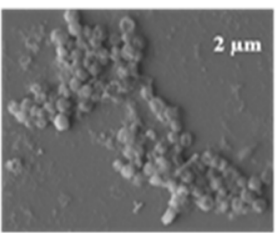

(h)

Figure 2. Visualization of enzyme effect on bacterial biofilms. (a)-(d): $1 \% \mathrm{CV}$ staining of Escherichia coli (NCIM 2674), Salmonella enterica (NCIM 2257), pseudomonas aeruginosa (NCIM 2200), Salmonella enterica NCIM 2257 respectively without enzymatic treatment (Control) (e)-(h) $1 \% \mathrm{CV}$ staining of all above respective biofilms with $5 \mathrm{mg}$ of crude enzyme treatment in $50 \mathrm{mM}$ citrate buffer $\mathrm{pH} 4.5$ for $1 \mathrm{~h}$. The magnification is 100x with oil immersion lense. 
bacterial biofilms. However, at $\mathrm{pH}$ 6.0, enzyme showed around less than $15 \%$ of biofilm reduction for all tested bacterial biofilms (Figure 3). Maximum biofilms reduction was obtained at $50^{\circ} \mathrm{C}$ with decrease in biofilm degradation at temperatures $40^{\circ} \mathrm{C}$ as shown in the figure (Figure $4(\mathrm{a})$ ). The effect of temperature on biofilm

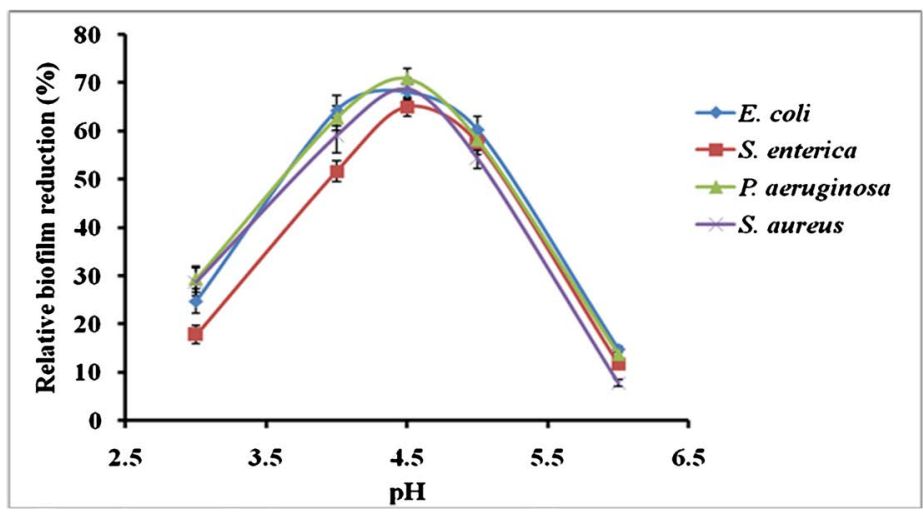

Figure 3. Effect of $\mathrm{pH}(3-6)$ on Biofilm reduction using $5 \mathrm{mg}$ of enzyme and incubated at $50^{\circ} \mathrm{C}$ for $1 \mathrm{~h}$.

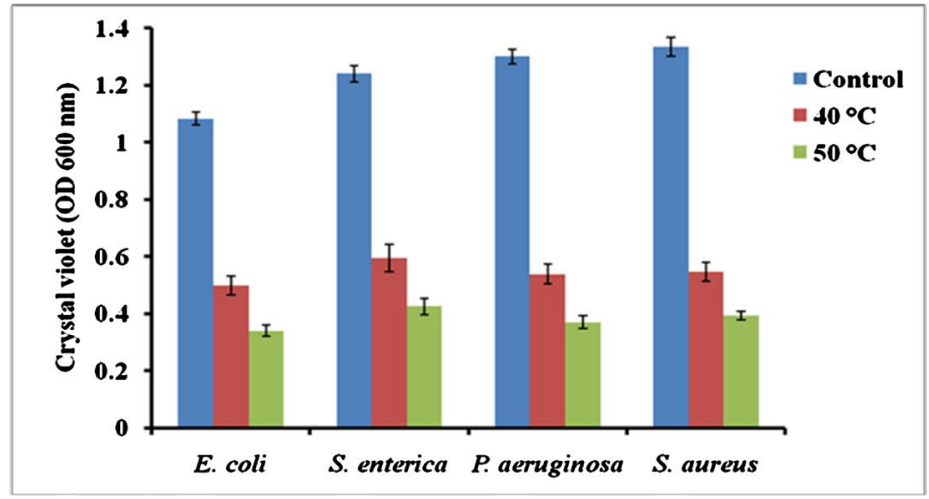

(a)

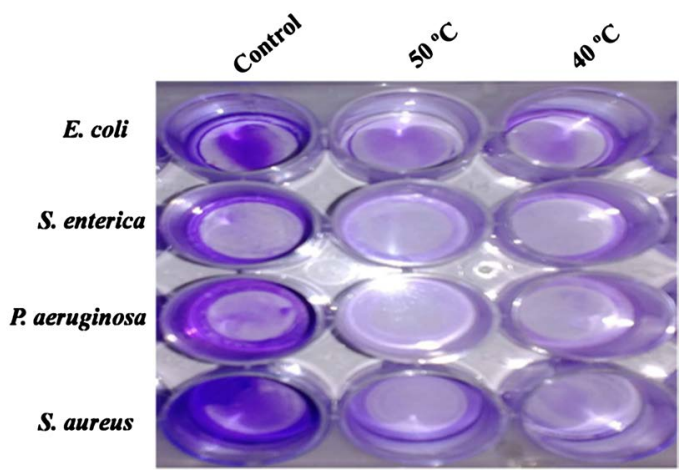

(b)

Figure 4. (a) Effect of temperature on Biofilm reduction using $5 \mathrm{mg}$ of enzyme and incubated at different temperature for $1 \mathrm{~h}$. The biofilms incubated in citrate buffer with no enzyme were considered as control; (b) Wells of crystal violet staining with control biofims of each bacterial strain followed by enzyme treated using $5 \mathrm{mg}$ of total protein content at different temperature for $1 \mathrm{hr}$ of incubation time. The biofilms incubated in citrate buffer with no enzyme were considered as control. 
degradation was also evaluated using CV assay (Figure 4(b)) and it showed similar pattern.

\subsection{Estimation of Carbohydrate and Protein from Biofilm}

The carbohydrate and protein content of enzyme treated and untreated bacterial biofilms has been summarized in Table 2. After enzymatic treatment, the carbohydrate and protein content of the biofilms was found to be reduced which is indicative of actions of cellulase, amylase and protease enzymes present in the enzyme preparation.

\section{Discussion}

One of the prominent features of the biofilms is the exo-polysaccharide (EPS) matrix that embeds the associated bacteria. This matrix plays a major role in protection of associated bacteria due to its structural stability in addition to its role in nutrient delivery and genetic transfer. However, majority of the antimicrobial agents do not reach the embedded bacterial cells due to the presence of biofilms formed by the bacteria which act as a barrier and protect the bacterial cells. Therefore, the disruption of the biofilm matrix is essential for reducing the defenses of the embedded bacteria. The matrix (EPS) contains three components namely, carbohydrates, proteins and extracellular DNA (eDNA). Active degradation of matrix components is mediated by number of compounds. DNases have been used for degradation of eDNA in the biofilms leading to disruption of biofilm matrix [22] [23]. However, there are certain limitations in using DNases since they are effective only on nascent biofilms and not on matured biofilms. In addition, DNases are expensive and hence their use in biofilm disruption is limited. Though most of the compounds are unable to degrade matured biofilms, nitric oxide [24], cis-2 decenoic acid [25] and anti-biofilm peptide [26] showed both prevention and disruption of $P$. aeruginosa biofilms. However, these compounds required more than $24 \mathrm{~h}$ incubation for efficient degradation of $P$. aeruginosa established biofilms. Antimicrobial peptides such as glycoside or acid hydrolases produced by microbes are most effective in degradation of biofilm components leading to disruption of structural integrity of the matrix [12] [27]. A number of proteases, especially serine proteases, and amylases showed the

Table 2. Comparison of total carbohydrate and protein content of each biofilm without enzyme/enzyme treated biofilms.

\begin{tabular}{ccccc}
\hline \multirow{2}{*}{ Organism } & \multicolumn{2}{c}{ Without Enzyme } & \multicolumn{2}{c}{ Enzyme treated } \\
\cline { 2 - 5 } & Carbohydrate $(\mu \mathrm{g})$ & Protein $(\mu \mathrm{g})$ & Carbohydrate $(\mu \mathrm{g})$ & Protein $(\mu \mathrm{g})$ \\
\hline E. coli $($ NCIM 2674$)$ & $88.65 \pm 2.88$ & $46.52 \pm 1.1$ & $10.88 \pm 0.56$ & $7.75 \pm 0.52$ \\
S. enterica & $67.16 \pm 1.64$ & $51.23 \pm 0.98$ & $11.62 \pm 0.73$ & $8.42 \pm 0.34$ \\
P. aeruginosa & $102.09 \pm 2.32$ & $40.23 \pm 1.25$ & $13.25 \pm 0.82$ & $6.24 \pm 0.44$ \\
S. aureus & $59.1 \pm 1.54$ & $35.11 \pm 1.02$ & $7.24 \pm 0.48$ & $5.57 \pm 0.32$ \\
\hline
\end{tabular}


capability of degrading biofilms with varying degrees of success [28] [29]. In our study, the enzyme preparation produced by $P$. janthinellum, EU2D-21 consisted of cellulase, amylase and protease enzymes when grown in cellulose containing medium. It appears to be a potent disruptor/degrader of the biofilms produced by E.coli, $S$. enterica, $P$. aeruginosa and $S$ aureus. Maximum biofilm degradation was found within $1 \mathrm{~h}$ against E. coli and $P$. aeruginosa showing $80 \%$ and $78 \%$ biofilm reduction respectively in terms of carbohydrate removal. Aspergillus clavatus MTCC 1323 produce enzyme preparation with protease, amylase and pectinase activities under solid state fermentation. This enzyme degraded the biofilms of Pseudomonas aeruginosa, Bacillus subtilis and Staphylococcus aureus after 7 days of incubation [11]. Newly formulated enzyme cleaners, known as Deconex Prozyme Active consisted of mixture of four enzymes viz. protease, polysaccharidases, lipases and DNases. This enzyme formulation degraded 95\% of the biofilms formed by clinical isolates of Pseudomonas aeruginosa and Staphylococcus aureus [30]. Deconex Prozyme Active was proved to be the best in the removal of biofilms of clinical isolates when compared to the commercially available enzymatic detergents. Our enzyme preparation pf $P$. janthinellum is comparable to commercial enzyme formulation (deconex Prozyme active) which can cleave around $90 \%$ biofilm produced by Pseudomonas aeruginosa and Staphyloccus aureus. Watters et al. [10] tested commercially available á-amylase, bromelain, lysostaphin and papain against the biofilms of $S$. aureus. They found maximum biomass was decreased (98\%) by á-amylase, bromelain, and papain whereas lysostaphin reduced the biomass up to 75\%. Biofilms formed by $\mathrm{Myco}$ bacterium tuberculosis is primarily composed of polysaccharides with cellulose as a key component [18]. Our $P$. janthinellum enzyme could be the potential candidate to degrade such cellulose containing biofilms to prevent $M$. tuberculosis infections.

\section{Conclusion}

Bacterial biofilms are single or multispecies microbial communities that are composed of cells embedded in self-produced extracellular polymeric substances (EPS). These biofilms protect the embedded bacteria from sheer stress, disinfectants, host immune defenses and antibiotics which lead to perpetual bacterial infections. The use of novel therapies to combat perpetual bacterial infections is a promising strategy to improve patient outcomes. The most commonly used enzymes for dispersal of biofilms are glycoside hydrolases such as DNase, amylases, proteases, and cellulases. Our study focused on evaluation of extracellular enzyme preparation of Penicillium janthinellum EU2D-21 for degradation of biofilms formed by Escherichia coli, Stphylococcus aureus, Pseudomonas aeruginosa and Salmonella enterica. The enzyme of $P$. janthinellum EU2D-21 consisted of cellulase, protease and amylase which degraded the selected bacterial biofilms using within $1 \mathrm{~h}$ of incubation. The carbohydrate and protein content of treated biofilm were drastically reduced indicating the biofilm degrading abil- 
ity of the enzyme. Future studies will be carried out on the degradation of biofilms formed by clinical bacterial cultures isolated from wound pathogens.

\section{Conflicts of Interest}

The authors declare no conflicts of interest regarding the publication of this paper.

\section{References}

[1] Yang, L., Hengzhuang, W., Wu, H., Damkiaer, S., Jochumsen, N., Song, Z., Givskov, M., Hoiby, N. and Molin, S. (2012) Polysaccharides Serve as Scaffold of Biofilms Formed by Mucoid Pseudomonas aeruginosa. FEMS Immunology and Medical Microbiology, 65, 366-376. https://doi.org/10.1111/j.1574-695X.2012.00936.x

[2] Sheppard, D.C. (2011) Molecular Mechanism of Aspergillus fumigatus Adherence to Host Constituents. Current Opinion in Microbiology, 14, 375-379. https://doi.org/10.1016/j.mib.2011.07.006

[3] Høiby, N., Bjarnsholt, T., Givskov, M., Molin, S. and Ciofu, O. (2010) Antibiotic Resistance of Bacterial Biofilms. International Journal of Antimicrobial Agents, 35, 322-332. https://doi.org/10.1016/j.ijantimicag.2009.12.011

[4] Mishra, M., Byrd, M.S., Sergeant, S., Azad, A.K., Parsek, M.R., McPhail, L., Schlesinger, L.S. and Wozniak, D.J. (2012) Pseudomonas aeruginosa Psl Polysaccharide Reduces Neutrophil Phagocytosis and the Oxidative Response by Limiting Complement-Mediated Opsonization. Cellular Microbiology, 14, 95-106. https://doi.org/10.1111/j.1462-5822.2011.01704.x

[5] Poterra, C. (1999) Forging a Link between Biofilms and Disease. Science, 283, 1837-1839. https://doi.org/10.1126/science.283.5409.1837

[6] Cady, N.C., McKean, K.A., Behnke, J., Kubec, R., Mosier, A.P., Kasper, S.H., Burz, D.S. and Musah, R.A. (2012) Inhibition of Biofilm Formation, Quorum Sensing and Infection in Pseudomonas aeruginosa by Natural Products-Inspired Organosulfur Compounds. PLOS One, 7, e38492. https://doi.org/10.1371/journal.pone.0038492

[7] Kim, H.-S., Lee, S.-H., Byun, Y. and Park, H.D. (2015) 6-Gingerol Reduces Pseudomonas aeruginosa Biofilm Formation and Virulence via Quorum Sensing Inhibition. Science Reports, 5, 8656. https://doi.org/10.1038/srep08656

[8] Rajput, A., Thakur, A., Sharma, S. and Kumar, M. (2018) aBiofilm: A Resource of Anti-Biofilm Agents and Their Potential Implications in Targeting Antibiotic Drug Resistance. Nucleic Acids Research, 46, D894-D900.

https://doi.org/10.1093/nar/gkx1157

[9] Kang, C.-I., Kim, S.-H., Kim, H.-B., Park, S.-W., Choe, Y.-J., Oh, M.-D., Kim, E.-C. and Choe, K.-W. (2003) Pseudomonas aeruginosa Bacteremia: Risk Factors for Mortality and Influence of Delayed Receipt of Effective Antimicrobial Therapy on Clinical Outcome. Clinical Infectious Disease, 37, 745-751. https://doi.org/10.1086/377200

[10] Watters, C.M., Burton, T., Kirui, D.K. and Millenbaugh, N.J. (2016) Enzymatic Degradation of in Vitro Staphylococcus aureus Biofilms Supplemented with Human Plasma. Infection and Drug Resistance, 9, 71-78.

[11] Singh, V., Verma, N., Banerjeea, B., Vibhaa, K., Haquec, S. and Tripathi, C.K.M. (2015) Enzymatic Degradation of Bacterial Biofilms Using Aspergillus clavatus MTCC 1323. Microbiology, 84, 59-64. https://doi.org/10.1134/S0026261715010130 
[12] Snarr, B.D., Bakerc, P., Bamfordc, N.C., Satoa, Y., Liue, H., Lehouxb, M., Gravelat, F.N., Ostapska, H., Shane R. Baistrocchia, S.R., Ceronea, R.P., Fillere, E.E., Parsek, M.R., Fillere, S.G., Howell, P.L. and Sheppard, D.C. (2017) Microbial Glycoside Hydrolases as Antibiofilm Agents with Cross-Kingdom Activity. Proceedings of National Academy of Sciences, USA, 114, 7124-7129. https://doi.org/10.1073/pnas.1702798114

[13] Blanchette, K.A. and Wenke, J.C. (2018) Current Therapies in Treatment and Prevention of Fracture Wound Biofilms: Why a Multifaceted Approach Is Essential for Resolving Persistent Infections. Journal of Bone and Joint Infection, 3, 50-67. https://doi.org/10.7150/jbji.23423

[14] Adsul M.G., Bastawde, K.B., Varma, A.J. and Gokhale, D.V. (2007) Strain Improvement of Penicilium janthinellum NCIM 1171 for Increased Cellulase Production. Bioresource Technology, 98, 1467-1473. https://doi.org/10.1016/j.biortech.2006.02.036

[15] Lowry, O.H., Rosebrough, N.J., Farr, A.L. and Randall, R.J. (1951) Protein Measurement with the Folin Phenol Reagent. Journal of Biological Chemistry, 193, 265-275.

[16] Bernfeld, P. (1955) Amylases, $\alpha$ and $\beta$. Methods in Enzymology, 1, 149-158. https://doi.org/10.1016/0076-6879(55)01021-5

[17] Sutar, I.I., Srinivasan, M.C. and Vartak, H.G. (1991) A Low Molecular Weight Alkaline Proteinase from Conidiobolus coronotus. Biotechnology Letters, 13, 119-124. https://doi.org/10.1007/BF01030462

[18] Trivedi, A., Mavi, P.S., Deepak Bhatt, D. and Kumar, A. (2016) Thiol Reductive Stress Induces Cellulose-Anchored Biofilm Formation in Mycobacterium tuberculosis. Nature Communications, 7, Article No. 11392. https://doi.org/10.1038/ncomms11392

[19] Zhang, A., Mu, H., Zhang, W., Cui, G., Zhu, J. and Duan, J. (2013) Chitosan Coupling Makes Microbial Biofilms Susceptible to Antibiotics. Scientific Reports, 3, Article No. 3364. https://doi.org/10.1038/srep03364

[20] Pan, M., Zhu, L., Chen, L., Qiu, Y. and Wang, J. (2010) Detection Techniques for Extracellular Polymeric Substances in Biofilms: A Review. BioResources, 11, 8092-8115.

[21] Masuko, T., Minami, A., Iwasaki, N., Majima, T., Nishimura, S. and Lee, Y.C. (2005) Carbohydrate Analysis by a Phenol-Sulfuric Acid Method in Microplate Format. Analytical Biochemistry, 339, 69-72. https://doi.org/10.1016/j.ab.2004.12.001

[22] Conover, M.S., Mishra, M. and Deora, R. (2011) Extracellular DNA Is Essential for Maintaining Bordetella Biofilm Integrity on Abiotic Surfaces and in the Upper Respiratory Tract of Mice. PLOS ONE, 6, e16861. https://doi.org/10.1371/journal.pone.0016861

[23] Hymes, S.R., Randis, T.M., Sun, T.Y. and Ratner, A.J. (2013) DNase Inhibits Gardnerella vaginalis Biofilms in Vitro and in Vivo. Journal of Infectious Disease, 207, 1491-1497. https://doi.org/10.1093/infdis/jit047

[24] Barraud, N., Hassett, D.J., Hwang, S.-H., Rice, S.A., Kjelleberg, S. and Webb, J.S. (2006) Involvement of Nitric Oxide in Biofilm Dispersal of Pseudomonas aeruginosa. Journal of Bacteriology, 188, 7344-7353. https://doi.org/10.1128/JB.00779-06

[25] Davies, D.G. and Marques, C.N.H. (2009) A Fatty Acid Messenger Is Responsible for Inducing Dispersion in Microbial Biofilms. Journal of Bacteriology, 191, 1393-1403. https://doi.org/10.1128/JB.01214-08 
[26] de la Fuente-Núñez, C., Reffuveille, F., Haney, E.F., Straus, S.K. and Hancock, R.E.W. (2014) Broad Spectrum Anti-Biofilm Peptide That Targets a Cellular Stress Response. PLOS Pathogens, 10, e1004152.

https://doi.org/10.1371/journal.ppat.1004152

[27] Baker, P., Hill, P.J., Snarr, B.D., Alnabelseya, N., Pestrak, M.J., Lee, M.L., Jennings, L.K., Tam, J., Melnyk, R.A., Parsek, M.R., Sheppard, D.C., Wozniak, D.J. and Howell, P.L. (2016) Exopolysaccharide Biosynthetic Glycoside Hydrolases Can Be Utilized to Disrupt and Prevent Pseudomonas aeruginosa Biofilms. Science Advances, 2, e1501632. https://doi.org/10.1126/sciadv.1501632

[28] Craik, C.S., Page, M.J. and Madison, E.L. (2011) Proteases as Therapeutics. Biochemical Journal, 435, 1-16. https://doi.org/10.1042/BJ20100965

[29] Loughran, A.J., Atwood, D.N., Anthony, A.C., Harik, N.S., Spencer, H.J., Beenken, K.E. and Smeltzer, M.S. (2014) Impact of Individual Extracellular Proteases on Staphylococcus aureus Biofilm Formation in Diverse Clinical Isolates and Their Isogenic sarA Mutants. Microbiologyopen, 3, 897-909.

https://doi.org/10.1002/mbo3.214

[30] Stiefel, P., Mauerhofer, S., Schneider, J., Maniura-Weber, K., Rosenberg, U. and Rena, Q. (2016) Enzymes Enhance Biofilm Removal Efficiency of Cleaners. Antimicrobial Agents and Chemotherapy, 60, 3647-3652.

https://doi.org/10.1128/AAC.00400-16 